Name : Wina illirian sevi rahmadanti

NRP: 130119025

KP B

\title{
INDONESIA TREASURE THRONE AND LOBSTER SEED
}

The country's economic growth in 2020 will rise by $6 \%$. this is because Indonesia has strong macroeconomics, structural reforms, and a number of national strategic projects(Sataloff et al., n.d.). One of them is in the fishery sector, in Indonesia in the determination of PERMEN KP no.1 year 2015 which prohibits the capture of lobster seed size in Indonesia(Erlania et al., 2017). This prohibition has an impact on coastal communities in terms of social and econmi, because it aims as an opportunity for local communities to cultivate lobster enlargement and become the eyes of the community's search fort. In 2012-2014 Indonesia became a major exporter of benih lobster, in Singapore, Malaysia to Hongkong. And every year the demand for lobster seeds continues to increase and the price is also increasingly expensive, at that time the public is not interested in expanding lobster cultivation, people prefer the export of lobster seeds in large scale at high prices to other countries. This is the beginning where the determination of the banning and catching of lobster seed size in Indonesia.

One in the east Lombok area, due to the increasing demand for lobster seeds and the cultivation that is still not done structurally causing imbalances in nature and resources, which makes the fishermen turn to catching lobster seeds massively. At that time the demand from importer countries was very high, making the yields decrease, and causing seed prices to soar. Pasa at that time also the technology of lobster enlargement cultivation in the local community is still not developed(Erlania et al., 2017).

Impact of lobster seed catching ban

This has an impact on coastal communities, especially those in the waters of central Lombok and east Lombok. Leads to a decrease in lobster seed catching up to $100 \%$. but there are still people who do catching lobster seeds and this causes a new problem that is illegal smuggling of lobster seeds. And the most affecting is the economic decline of the communities around the waters. The potential there is very profitable until previously the 
community working as fishermen turned into lobster seed catcher. The social impact is also very visible, namely the number of unemployed around the community and even increased crime. The availability of seeds for the enlargement of lobster cultivation is also not given due to the prohibition of catching lobster seeds. But the long-term positive impact is the richness of seed potential and the availability of lobsters in the wild that are not disturbed by the preservation of seed pupulation in nature as well as the enlargement of lobster cultivation naturally. From the data taken around the waters of east Lombok and surrounding areas, during lobster seed catching activity during the absence of a decrease in its population, it was only at the end of 2014 that there was a decrease in lobster seed catching(Erlania et al., 2017).

Lobster itself is an organism that lives at the bottom of the water,and its distribution depends on substrates in nature, the availability of food,and other organisms in the waters. Opens up opportunities for the cultivation of lobsters which is very interesting. Until now the cultivation of lobster enlargement is still done in a conventional way among the surrounding community. One aspect of obstacles in the enlargement of lobsters in Indonesia is a relatively long maintenance period, seeds are still in nature, disease attacks and the availability of appropriate artificial feed in Indonesia. The disadvantage is that the feed obtained is influenced by the season, if using ordinary artificial pellet feed the growth produced is relatively very low. Lobster cultivation is a very possible strategy to deal with the increase in lobster exports that can not be met by catches from nature(Erlania et al., 2017). 


\section{LIBRARY LIST}

Erlania, E., Radiarta, I. N., \& Haryadi, J. (2017). Status Pengelolaan Sumberdaya Benih Lobster Untuk Mendukung Perikanan Budidaya: Studi Kasus Perairan Pulau Lombok. Jurnal Kebijakan Perikanan Indonesia, 8(2), 85. https://doi.org/10.15578/jkpi.8.2.2016.85-96

Sataloff, R. T., Johns, M. M., \& Kost, K. M. (n.d.). No 主観的健康感を中心とした在宅高齢 者における健康関連指標に関する共分散構造分析Title. 